\title{
The study of the Mineral Composition in the Granite Rocks in the Village of Lhok Pawoh, South Aceh District
}

\author{
Bakruddin $^{\mathrm{a}, *}$, Arnold Rikardo Sihombing ${ }^{\mathrm{a}}$, Zulkarnain Jalil ${ }^{\mathrm{b}}$ \\ ${ }^{a}$ Departement of Industrial Engineering, Polytehcnic of Aceh Selatan, Tapaktuan, 23711, Indonesia \\ ${ }^{b}$ Department of Physics, Syiah Kuala University, Banda Aceh, 23111, Indonesia \\ bakry.klt@gmail.com*
}

Article history:

Accepted

Keywords:

Granite Rocks

Lhok Pawoh

X-ray Fluorescence

Scanning Electron Microscopy
The potential of non-metallic mineral resources in South Aceh is diverse, such as one of the granite rocks located in Lhok Pawoh village, Sawang sub district. Granite rocks have a distinctive characteristic based on their constituent minerals. This research is to obtain information about the constituent minerals in the granite rocks of Lhok Pawoh village. The research method uses X-ray Fluorescence (XRF) technique, then the observation of surface morphology is done by Scanning Electron Microscopy (SEM). The XRF test results show that there are 14 phases of a mineral identified as the constituent mineral phase, where the very dominant $\mathrm{SiO} 2$ mineral reaches $67.9 \%$. The mineral phase of $\mathrm{Al} 2 \mathrm{O} 3$ by $15 \%$, and the third $\mathrm{Fe} 2 \mathrm{O} 3$ of $6.03 \%$, followed by the other minor phase of minerals. As for the morphological observation, the dominant element appears in several factors, namely $\mathrm{Si}, \mathrm{O}$, and $\mathrm{Al}$. From the two testing and analysis methods, the granite stone of the village Lhok Pawoh is dominating by silica elements, which can visually be seen in white.

Copyright (C) 2020 Politeknik Aceh Selatan. All rights reserved.

\section{Introduction}

South Aceh has diverse mineral resources. The inventory activity and investigation of nonmetallic minerals carried out in the year 2006. It is identified that as many as nine types of minerals belong to the non-metallic group of granite rocks [1]. Especially in the area of Lhok Pawoh Village, Sawang sub district. Granite rocks are formed from intrusive igneous rocks that include a wide range of constituent compounds such as silica (SIO2) [2] [3]. The formation of granite rocks in the region is geology formed from rock formations precipitated by the metamorphic rocks of the Kampleks Gneis Meukek. The rock formations were then been by the Instrusi Sibubung consisting of granite phases of Leukocratik and Mafik [1]. However, to date, there has been no fundamental research related to mineralogy and the composition contained within the rocks. Therefore, it is necessary to study mineral identification in the granite rock of Lhok Pawoh village. In this research method, used techniques are the observation of X-ray Fluorescence and Scanning Electron Microscopy. The method is very supportive of the fundamental study of rocks. Some previous studies using X-ray Fluorescence technique analysis are to identify the content and composition of gold rocks [4]. Another study applied for studies on iron ore rocks [5]. Next is the implementation of the identification of elemental compositions on heavy metals [6]. While the observation of microstructures with the analysis technique of Scanning Electron Microscopy (SEM) Previous research said, that can be used to identify the mineral of rocks contained in the inside can be done in jade [7]. From some of the above studies described, both methods are appropriate to apply in this study. 


\section{Methodology}

Sample of granite rocks in this research from Lhok Pawoh Village, Sawang Sub-district, South Aceh Regency. Then the sample of granite rocks was taken in small chunks, and the samples of rocks were cleared from the dirt. The next process is the samples of rocks mashed using ALU and mortar to powder size [8] [9]. Sample of granite rocks in this research from Lhok Pawoh Village, Sawang Sub-district, South Aceh Regency. Then the sample of granite rocks was taken in small chunks, and the samples of rocks were cleared from the dirt. The next process is the samples of rocks mashed using ALU and mortar to powder size [8] [9]. Further, the sample of rock is carried out in the laboratory using X-Ray Fluorescence (XRF), it is to know the mineral content, composition and percentage of elements contained in granite rock, and Scanning Electron (SEM) test combined with the Energy Dispersive X-Ray Spectroscopy (EDX) for the observation of surface morphology on rock samples [2].

\section{Results and Discussion}

Based on the results of the test using X-Ray Fluorescence in granite rock samples taken from Lhok Pawoh village, Sawang District, South Aceh Regency, there are 14 phases of a mineral identified. Each of these results can be seen in table 1. Granite rock samples have a mineral phase that appears predominantly $\mathrm{SiO} 2$ mineral with a percentage of $67.9 \%$, followed by the mineral phase $\mathrm{A} 12 \mathrm{O} 3$ as the second dominant percentage of $15 \%$, and the third phase of the mineral $\mathrm{Fe} 2 \mathrm{O} 3$ with a percentage of $6.03 \%$, and then followed by another phase of mineral as the minor phase. The difference in mineral content and the percentage of a mineral depends on its geological process, which is influenced by the dissolving process of other minerals and the hydrothermal changes during the journey from the Earth's stomach to rise to the surface of the Earth due to tectonic and volcanic events [7]. Based on the results of the test using X-Ray Fluorescence in granite rock samples taken from Lhok Pawoh village, Sawang District, South Aceh Regency, there are 14 phases of a mineral identified. Each of these results can be seen in table 1. Granite rock samples have a mineral phase that appears predominantly $\mathrm{SiO} 2$ mineral with a percentage of $67.9 \%$, followed by the mineral phase $\mathrm{Al} 2 \mathrm{O} 3$ as the second dominant percentage of $15 \%$, and the third phase of the mineral $\mathrm{Fe} 2 \mathrm{O} 3$ with a percentage of $6.03 \%$, and then followed by another phase of mineral as the minor phase. The difference in mineral content and the percentage of a mineral depends on its geological process, which is influenced by the dissolving process of other minerals and the hydrothermal changes during the journey from the Earth's stomach to rise to the surface of the Earth due to tectonic and volcanic events [7].

Table 1. XRF Data on Granite rock samples of Lhok Pawoh village

\begin{tabular}{ccc}
\hline No & Chemical Compounds & Percentage \% \\
\hline 1 & $\mathrm{SiO}_{2}$ & 67,9 \\
2 & $\mathrm{Al}_{2} \mathrm{O}_{3}$ & 15 \\
3 & $\mathrm{Fe}_{2} \mathrm{O}_{3}$ & 6,03 \\
4 & $\mathrm{~K}_{2} \mathrm{O}$ & 5,73 \\
5 & $\mathrm{CaO}$ & 3,71 \\
6 & $\mathrm{TiO}_{2}$ & 1,24 \\
7 & $\mathrm{MnO}$ & 0,18 \\
8 & $\mathrm{SrO}$ & 0,15 \\
9 & $\mathrm{Eu}_{2} \mathrm{O}_{3}$ & 0,1 \\
10 & $\mathrm{Rb}_{2} \mathrm{O}$ & 0,091 \\
11 & $\mathrm{CuO}_{12}$ & 0,047 \\
12 & $\mathrm{Cr}_{2} \mathrm{O}_{3}$ & 0,037 \\
\hline
\end{tabular}




\begin{tabular}{ccc}
\hline No & Chemical Compounds & Percentage \% \\
\hline 13 & $\mathrm{~V}_{2} \mathrm{O}_{5}$ & 0,03 \\
14 & $\mathrm{BaO}$ & 0,03 \\
\hline
\end{tabular}

Then based on the result of micro structure SEM test on the sample of granite rocks as shown in Figure 1 and Figure 2, with each scale of $200 \mu \mathrm{m}$ and $500 \mu \mathrm{m}$.

Figure 1. The morphological structure of the sample surface of granite Rock village Lhok Pawoh with a scale of $200 \mu \mathrm{m}$.

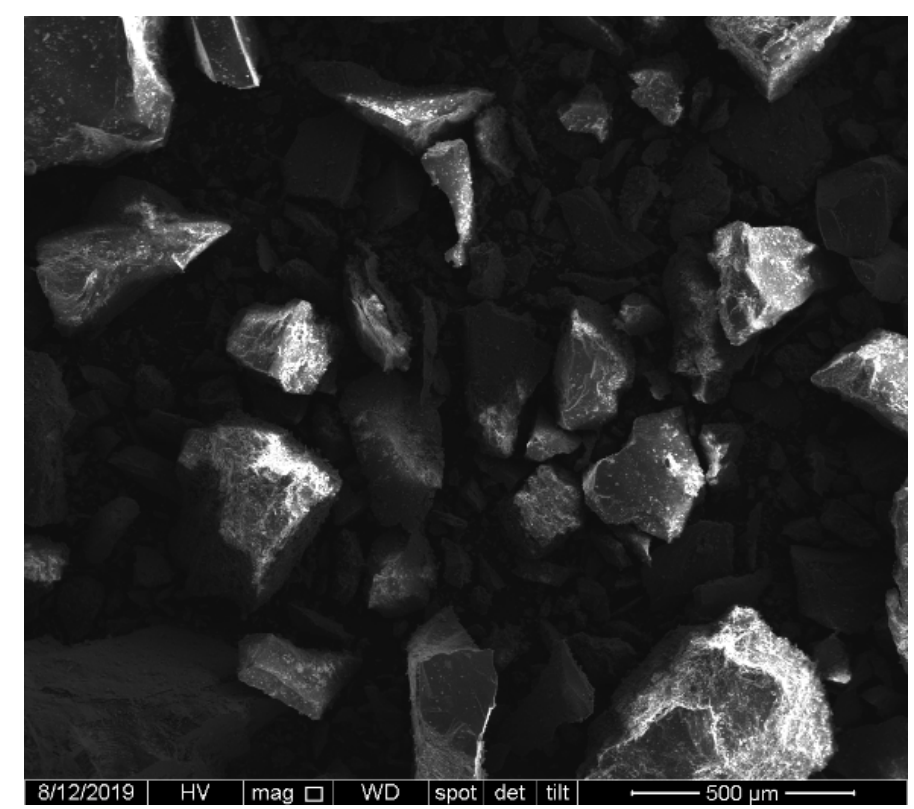

Figure 2. The morphological structure of the sample surface of granite Rock village Lhok Pawoh with a scale of $500 \mu \mathrm{m}$. 
Based on Figure 1 and figure 2 above the morphology of the surface in irregular rock samples with varying grain sizes. Visually visible color is a dark color and white color. The dominant color that appears to be black, brown, and white, it can be assumed that the main constituent elements of these granite rock samples are identical with the elements $\mathrm{Al}, \mathrm{Mg}$, and $\mathrm{Si}$. It can also be assumed that it indicates the dominant elemental silica or constituent element that has a high atomic number [10]. EDX Analysis results provide information on the composition of the elements contained in the sample rocks, as shown in Figure 3 below.

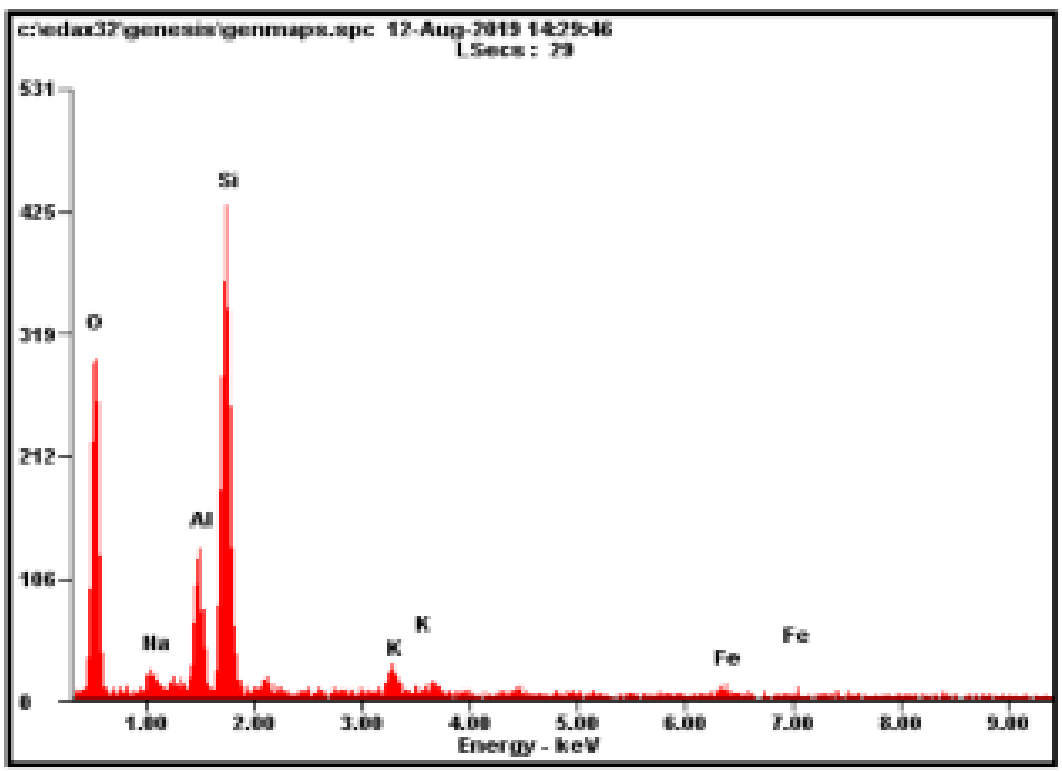

Figure 3. Diffraction pattern of SEM-EDX granite rock samples Lhok Pawoh Village

The EDX analysis results that the composition of the constituent elements in the granite rock samples of Lhok Pawoh Village is the O element of the baseline $50.88 \mathrm{wt} \%$, then the Si element is $30.97 \mathrm{wt} \%$, and the $\mathrm{Al}$ element is $09.46 \mathrm{wt} \%$, besides the element, there are also other elements namely the Na Naasar element $02.72 \mathrm{wt} \%$, the element $\mathrm{Fe}$ is as broad as $03.21 \mathrm{wt} \%$, and $\mathrm{K}$ is as broad as $02.75 \mathrm{wt} \%$.

\section{Conclusion}

Based on the results obtained from the X-ray Fluorescence and SEM-EDX test, granite rock samples of Lhok Pawoh Village, Sawang Sub-district, South Aceh District is the dominant mineral phase as a constituent of granite rock namely $\mathrm{Si}, \mathrm{Al}, \mathrm{Fe}$.

\section{Acknowledgment}

The author would like to thanks the Direktorat Jenderal Penelitian dan Pengabdian Kepada Masyarakat who has funded this research through the Dosen Pemula research Program year 2019. And thank you also to the Laboratorium Mineral dan Material Maju (Sentral) Faculty and Natural Sciences (FMIPA) University of Malang for the opportunity to conduct sample testing.

\section{References}

[1] B. S. Zulfikar, Iwan Aswan H., Corry Karangan, "Inventarisasi dan Penyelidikan Mineral non Logam Kabupaten Aceh Selatan, Proceeding Pemaparan Hasil-Hasil Lapangan dan non Lapangan. Pusat Sumber Daya Mineral, 2006.

[2] B. Bin, D. Iman, and A. Rikardo, "Minerals Identification and Analysis of Granite Rocks in South Aceh District Using X-Ray Diffraction ( XRD ),” vol. 4, no. 2, pp. 79-83, 2019. 
[3] G. Bayrak and S. Yilmaz, "Granite based glass-Ceramic materials," Acta Phys. Pol. A, vol. 125, no. 2, pp. 623-625, 2014.

[4] A. Maulana, K. Watanabe, A. Imai, and K. Yonezu, "Origin of Magnetite- and Ilmenite-series Granitic Rocks in Sulawesi, Indonesia: Magma Genesis and Regional Metallogenic Constraint," Procedia Earth Planet. Sci., vol. 6, pp. 50-57, 2013.

[5] A. Rahwanto and Z. Jalil, "Kajian Awal Karakteristik Mineral Magnetik Bijih Besi Manggamat, Aceh Selatan,” Pros. Semirata FMIPA Univ. Lampung, pp. 203-206, 2013.

[6] M. Zainuri, J. Fisika, and U. Negeri, “(CaCO3 DAN SiO2),” vol. 2, no. 1, pp. 20-29, 2012.

[7] R. Nasution, "Applying SEM-EDX Techniques to Identifying the Types of Mineral of Jades (Giok) Takengon, Aceh," vol. 15, no. 2, 2015.

[8] Bakruddin and S. Audah, "Utilization of GPS data in the effort of Mineral Identification in Granite Rocks Using X-Ray Diffraction in Samadua District, South Aceh," vol. 4, no. 1, pp. 16, 2019.

[9] Bakruddin, W. Utama and D. Warnana, "ISSN 2581-1274 Analisa Batuan Alterasi Panas Bumi Arjuno-Welirang Berdasarkan Sifat Mineraloginya," vol. 2, no. 2, pp. 3-6, 2017.

[10] Tutu, Rais., dkk "Studi Analisis Karakterisasi dan Mikrostruktur Mineral Sedimen Sumber Air Panas Sulili di Kabupaten Pinrang," Jurnal dan Pendidikan Fisika. Jilid 11, No. 1, pp. 192-201, 2015. 